Research Article

www.ijrap.net (ISSN:2229-3566)

\title{
SCREENING OF MANGO LEAVES (MANGIFERA INDICA L.) VARIETIES IN INDONESIA FOR ANTIBACTERIAL ACTIVITY IN STAPHYLOCOCCUS AUREUS
}

Novi Fajar Utami ${ }^{1 *}$, Prasetyorini ${ }^{2}$, Rike Khaerunissa ${ }^{1}$, Indria Pramitasari ${ }^{1}$, Ade Herbayani ${ }^{1}$

${ }^{1}$ Department of Pharmacy, Faculty of Mathematics and Natural Sciences, Universitas Pakuan, Indonesia

${ }^{2}$ Department of Biology, Faculty of Mathematics and Natural Sciences, Universitas Pakuan, Indonesia

Received on: 10/02/20 Accepted on: 10/03/20

\author{
*Corresponding author \\ E-mail: novi.utami@unpak.ac.id
}

DOI: $10.7897 / 2277-4343.110234$

\begin{abstract}
Acne is a common chronic skin disease that involves the blockage and inflammation of the polysebase unit which causes one of them is the bacterial infection of Staphylococcus aureus. In Indonesia, there are several varieties of mango plants (Mangifera indica L), including gedong mango, apple mango, simanalagi mango, and arumanis mango. The leaves of the mango are very abundant and have not been widely used by Indonesian people as traditional medicine as bacterial infection of Staphylococcus aureus. The main objective has investigated the presence of phytochemical constituents and antibacterial activity from several varieties of mango in Indonesia. Mango leaves varieties were extracted with $96 \%$ ethanol and screened for phytochemical constituents with standard procedure. The antibacterial activities of some mango leaves varieties were examined by minimum inhibitory concentration and inhibitory width by agar well diffusion and dilution method. Based on the results of phytochemical testing, four varieties of mango leaves in Indonesia, contain volatile oils, carbohydrates, glycosides, sterols, triterpenes, flavonoids, coumarins, tannins and saponins and the absence of anthraquinones, alkaloids and cardiac glycosides. In the antibacterial activity, arumanis mango shows the most potent inhibitory activity against Staphylococcus aureus with a MIC value of $40 \%$ and the width of the inhibitory value of $3.60 \mathrm{~mm}$ at a concentration of $40 \%$.
\end{abstract}

Keyword: Mangifera indica L, Indonesia, Staphylococcus aureus, Leaves, Width of Inhibition

\section{INTRODUCTION}

Acne is the most common inflammatory skin disease from which $70-95 \%$ of all teenagers temporarily suffer. About $19 \%$ acne continues also to adulthood ${ }^{1}$. Acne is characterized by hyperactivity of sebaceous glands. Increased sebum production (seborrhea) is triggered by a transient hormonal imbalance in favor of testosterone. Principally, acne shows an epidermal hyperproliferation that causes follicular hyperkeratosis (comedones) and perifollicular inflammation (papules and pustules). The most important pathogen linked to acne-prone skin is Propionibacterium acnes (P. acnes) ${ }^{2}$. P. acnes is a Grampositive, anaerobic, immobile bacterium that populates skin pores and hair follicles. It grows on sebaceous, greasy skin and uses sebum as a nutrient source ${ }^{3}$. Sebum plays a role in the pathogenesis of acne ${ }^{4}$ because $P$. acnes releases lipases, proteases, and hydrolases into the sebum which promotes oxidative stress, inflammation and tissue destruction ${ }^{5}$. Acne is characterized by non-inflammatory, open or closed comedones and by inflammatory papules, pustules, and nodules ${ }^{6}$ Besides $P$. acnes also aerobic bacteria such as the skin commensal Staphylococcus aureus (S. aureus) are increased in their number in acne lesions ${ }^{7}$. S. aureus is a harmless Gram-positive coccus that populates skin and mucosa ${ }^{8}$ Mangifera indica $\mathrm{L}$. is considered as one of the main tropical fruits in the world believed to be originated from Asia ${ }^{9}$. Indonesia has several varieties of mango plants (Mangifera indica L), including gedong mango, apple mango, simanalagi mango, and arumanis mango. The leaves of the mango plant are very abundant and have not been widely used by Indonesian people as traditional medicine ${ }^{10}$. Among these, polyphenols (flavonoids, xanthones, and phenolic acids) are the most abundant compound types in Mangifera indica ${ }^{11}$. Phytochemical Study of different cultivars of Mangifera indica
L. Family Anacardiaceae. CU Theses. Mangifera indica is a plant that has the same genus as ground mango (Mangifera foetida L.) so that four varieties of mango plants in Indonesia are thought to have the same secondary metabolite content as antibacterial namely flavonoid compounds, alkaloids, tannins, and saponins ${ }^{12}$. Therefore, it is needed to determine the antibacterial activity of ethanolic extract of several mango varieties in Indonesia that may have the potential against Staphylococcus aureus.

\section{MATERIALS AND METHODS}

\section{Material Test}

Samples gedong mango leaves, apple mango leaves, simanalagi mango leaves, and arumanis mango leaves were collected in May 2019 and identified by The Center for Plant Conservation from Bogor Botanical Garden with the authentic number is B/314/IPH.3/KS/IV/2019. The specimen was deposited by Herbarium of Pharmacognosy Laboratorium Department of Pharmacy, Universitas Pakuan, Bogor, Indonesia (24/Mei/HLF/UNPAK).

\section{Chemicals}

Ethanol 96\% (Sigma Chemical Co.), Sodium Lauryl Sulfate (Brataco $\left.{ }^{\circledR}\right), \mathrm{NaCl}$ (Brataco $\left.{ }^{\circledR}\right)$, Propylene Glycol (Brataco $\left.{ }^{\circledR}\right)$, Citric acid (Brataco $\AA)$, aquadest, chloroform (Merck $\AA), \mathrm{HCl}$ (Merck $\left.{ }^{\circledR}\right)$, Reagent dragendorf, Reagent Mayer, Reagent Wagner, magnesium powder (Brataco $\left.{ }^{\circledR}\right), \mathrm{FeCl} 3$ (Merck $\left.{ }^{\circledR}\right)$.

\section{Simplicia powder manufacturing}

Gedong, apples, simanalagi and arumanis mango leaves weighed 
$2.5 \mathrm{~kg}$ each and dried using an oven at $45^{\circ} \mathrm{C}$. Dry Simplicia is ground to powder and sieved using a 40 mesh sieve and then weighed and stored in a clean and tightly closed container.

\section{Extraction}

Simplicia mango leave powder weighs 50 grams each, extracted with $96 \%$ ethanol as much as $750 \mathrm{ml}$ with a solvent ratio of 1:15. The maceration process is carried out for 3 days with remaceration. The pulp is removed, the resulting filtrate is collected and then evaporated with a rotary vaccum evaporator at $40^{\circ} \mathrm{C}$ and a speed of $100 \mathrm{rpm}$ until it becomes a thick extract and the results are calculated.

\section{Phytochemical test}

Detection of alkaloids: Extracts were dissolved individually in dilute Hydrochloric acid and filtered. Mayer's Test: Filtrates were treated with Mayer's reagent (Potassium Mercuric Iodide). The formation of a yellow-colored precipitate indicates the presence of alkaloids. Dragendroff's Test: Filtrates were treated with Dragendroff's reagent (solution of Potassium Bismuth Iodide). The formation of a red precipitate indicates the presence of alkaloids.

Detection of saponins: a) Froth Test: Extracts were diluted with distilled water to $20 \mathrm{ml}$ and this was shaken in a graduated cylinder for 15 minutes. The Formation of a $1 \mathrm{~cm}$ layer of foam indicates the presence of saponins.

Detection of tannins. Gelatin Test: The extract, 1\% gelatin solution containing sodium chloride was added. The formation of a white precipitate indicates the presence of tannins.

Detection of flavonoids. Alkaline Reagent Test: Extracts were treated with a few drops of sodium hydroxide solution. The formation of intense yellow color, which becomes colorless on the addition of dilute acid, indicates the presence of flavonoids.

\section{Determination of the minimum inhibitory concentration} (MIC)

The broth micro-dilution method was used to determine the MIC according to The European Committee on Antimicrobial Susceptibility Testing (EUCAST) ${ }^{14}$. The tested extracts were dissolved in $10 \%$ DMSO and diluted to the higher concentration. Then, a serial $1 / 2$ dilutions of extracts were prepared directly in a microtiter plate containing nutrient agar broth to obtain concentrations from 2.5 to $20 \mathrm{mg} / \mathrm{mL}$. The bacterial inoculum was added to give a final concentration of $5 \times 10^{5} \mathrm{CFU} / \mathrm{mL}$ in

each well. The positive control was used containing Amoxicillin as a standard drug at final concentrations from 0.125 to 128 $\mu \mathrm{g} / \mathrm{mL}$. The plate was covered with a sterile sealer and incubated for $24 \mathrm{~h}$ at $37^{\circ} \mathrm{C}$. The MIC was considered as the lowest concentration of the extract that completely inhibits the bacterial growth. The lower the MIC, the higher the activity of the extract.

\section{RESULTS AND DISCUSSION}

\section{Simplicia Powder and Extract}

The results show that the gedong mango has the highest yield of Simplicia with $50 \%$, and $\%$ extract yield $52 \%$.

\section{Characteristic Mango Leaf Extract}

Gedong mango has the best characteristics with a value of $25.316 \%$ water content, meets requirement not be more than $30 \%$ and $4.95 \%$ ash content with, a requirement of $3-5 \%{ }^{15}$.

\section{Phytochemical Identification}

Extract Mangifera indica positively contains flavonoid, alkaloids, tannin and saponin. The result is by the research ${ }^{6}$.

\section{Minimum Inhibition Concentration}

The results of testing the MIC shows that leaves of mango gedong at a concentration of $10 \%$, the leaves of mango arumanis at a concentration of $10 \%$, the leaves of mango simanalagi at a concentration of $12.5 \%$ and leaves of mango apple at a concentration of $25 \%$ does not exist the growth of bacteria marked by the zone clear in Petri dishes.

\section{The width of the area is hindering}

The results of it showed that the mango arumanis with a concentration of $40 \%$ has the best result compared with other varieties of mangoes with a value of width area hindering $3.6 \mathrm{~mm}$. Results of Testing can be seen in Figure 1.

\section{Antibacterial Data Analysis}

The results of statistical tests using the Kruskal Wallis method show that each extract concentration gives a significantly different effect and positive control gives a very real difference. So that all concentrations in the maceration extraction method have the potential to be antibacterial. The results of data analysis can be seen in Table 1 .

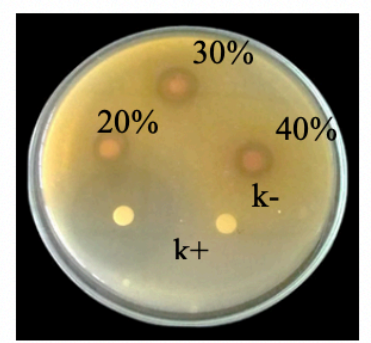

Mango Simanalagi

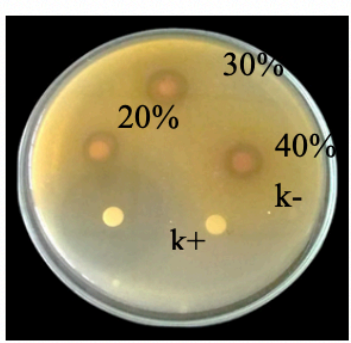

Mango Apel

Figure 1: Width of the area is hindering

Inhibitory Power Width Test $\mathrm{K}+=$ control positive (Amoxicillin) K- = control negative (DMSO) 
Table 1: Results of Antibacterial Data Analysis

\begin{tabular}{|c|c|c|c|}
\hline Types of Mango Leaves & Concentration $(\%)$ & The width of the area is hindering $(\mathrm{mm})$ & Information \\
\hline Gedong mango & $\begin{array}{l}\mathrm{K}(-) \\
20 \\
30 \\
40 \\
\mathrm{~K}(+)\end{array}$ & $\begin{array}{l}0^{\mathrm{a}} \\
2.47^{\mathrm{b}} \\
2.70^{\mathrm{c}} \\
3.17^{\mathrm{d}} \\
12^{\mathrm{e}}\end{array}$ & $\begin{array}{l}- \\
\text { Weak } \\
\text { Weak } \\
\text { Weak } \\
\text { Strong }\end{array}$ \\
\hline Arumanis Mango & $\begin{array}{l}\mathrm{K}(-) \\
20 \\
30 \\
40 \\
\mathrm{~K}(+)\end{array}$ & $\begin{array}{l}0^{\mathrm{a}} \\
2.60^{\mathrm{b}} \\
3.10^{\mathrm{c}} \\
3.60^{\mathrm{d}} \\
12^{\mathrm{e}}\end{array}$ & $\begin{array}{l}- \\
\text { Weak } \\
\text { Weak } \\
\text { Weak } \\
\text { Strong }\end{array}$ \\
\hline Simanalagi Mango & $\begin{array}{l}\mathrm{K}(-) \\
20 \\
30 \\
40 \\
\mathrm{~K}(+)\end{array}$ & $\begin{array}{l}0^{\mathrm{a}} \\
2.56^{\mathrm{b}} \\
2.90^{\mathrm{c}} \\
3.10^{\mathrm{d}} \\
12^{\mathrm{e}}\end{array}$ & $\begin{array}{l} \\
\text { Weak } \\
\text { Weak } \\
\text { Weak } \\
\text { Strong } \\
\end{array}$ \\
\hline Apple Mango & $\begin{array}{l}\mathrm{K}(-) \\
20 \\
30 \\
40 \\
\mathrm{~K}(+)\end{array}$ & $\begin{array}{l}0^{\mathrm{a}} \\
2.73^{\mathrm{b}} \\
3.06^{\mathrm{c}} \\
3.10^{\mathrm{cd}} \\
12^{\mathrm{e}}\end{array}$ & $\begin{array}{l}- \\
\text { Weak } \\
\text { Weak } \\
\text { Weak } \\
\text { Strong }\end{array}$ \\
\hline
\end{tabular}

\section{DISCUSSION}

Based on data from the results, Amoxicillin was used as positive controls and Dimethyl Sulphoxide (DMSO) was used as a negative control ${ }^{16}$. The results of the phytochemical testing state that mango leaves in Indonesia contain secondary metabolites such as alkaloids, tannins, flavonoids, and saponins which have an antibacterial mechanism of action.

Mechanism of action of alkaloids as an antibacterial is by way of interference with the components of the peptidoglycan of bacterial cell and as a result the lining of the cell walls are not fully formed which will lead to cell death and also by inhibiting the enzyme topoisomerase in bacterial cells ${ }^{17}$. Mechanism flavonoids as an antibacterial is that it can damage the permeability of the cell walls of microbes. The functional protein bind to the DNA of cells thus can inhibit the growth of microbes. Flavonoids can inhibit cell components that function to release antimicrobial substances. The cell component lipopolysaccharide is found membrane of the cell ${ }^{18}$. The mechanism of action of saponin as an antibacterial is that it can cause leakage of proteins and enzymes from within the cell ${ }^{19}$. Because the surface-active ingredient saponin is similar to detergent, so it will reduce the surface tension of the bacterial cell wall and damage membrane permeability.

Work with compounds in the flavonol, flavan-3-ol and flavolan classes suggest that they damage the cytoplasmic membrane (possibly by generating hydrogen peroxide and work with flavan3-ols, and isoflavones suggests that they inhibit nucleic acid synthesis (through topoisomerase 20 and/or dihydrofolate reductase inhibition). Also compounds in the flavonol, flavan-3ol and flavone classes have been shown to inhibit energy metabolism (through ATP synthase inhibition ${ }^{21}$ ).

The extracts of mango have been found sufficient activity against bacteria; Staphylococcus aureus, Streptococcus pyogenes, Streptococcus pneumoniae ${ }^{22}$. Antibacterial activity of mango extracts upon gram-positive, gram-negative bacteria and yeast Candida albicans was also demonstrated ${ }^{23}$.

\section{CONCLUSION}

The antibacterial activity arumanis mango leaves from Indonesia shows the most potent inhibitory activity against
Staphylococcus aureus with a MIC value of $40 \%$ and the width of the inhibitory value of $3.60 \mathrm{~mm}$ at a concentration of $40 \%$.

\section{ACKNOWLEDGMENTS}

The authors are thankful to the Department of Pharmacy, Universitas Pakuan for providing the laboratory facilities.

\section{REFERENCES}

1. Svensson, A., Ofenloch, R.F., Bruze, M., Naldi, L., Cazzaniga, S., Elsner, P., Goncalo, M., Schuttelaar, M.-L.A., Diepgen, T.L. Prevalence of skin disease in a populationbased sample of adults from five European countries. $B r . J$. Dermatol. 2018. 178, 1111-1118.

2. Jantarat, C., Sirathanarun, P., Chuchue, T., Konpian, A., Sukkua, G., Wongprasert, P., Jantarat, C., Sirathanarun, P., Chuchue, T., Konpian, A. In Vitro Antimicrobial Activity of Gel Containing the Herbal Ball Extract against Propionibacterium acnes. Sci. Pharm. 2018. 86, 8.

3. Sinha, P., Srivastava, S., Mishra, N., Yadav, N.P. New Perspectives on Antiacne Plant Drugs: Contribution to Modern Therapeutics. Available online: https://www.hindawi.com/journals/bmri/2014/301304/abs/ (accessed on 12 January 2019).

4. Dessinioti, C. Zouboulis, C.C., Katsambas, A.D., Kligman, A.M. Acne Pathogenesis: What We Have Learned Over the Years. In Pathogenesis and Treatment of Acne and Rosacea; Eds.; Springer: Berlin/Heidelberg, Germany, 2014. pp. 6170. ISBN 978-3-540-69375-8.

5. Isard, O., Knol, A.C., Ariès, M.F., Nguyen, J.M., Khammari, A., Castex-Rizzi, N., Dréno, B. Propionibacterium acnes activates the IGF-1/IGF-1R system in the epidermis and induces keratinocyte proliferation. J. Investig. Dermatol. 2011. 131, 59-66.

6. Chandrashekhar B.S., Anitha M., Ruparelia M., Vaidya P., Aamir R., Shah S. Tretinoin nanogel $0.025 \%$ versus conventional gel $0.025 \%$ in patients with acne vulgaris: A randomized, active controlled, multicen- tre, parallel group, phase iv clinical trial. J Clin Diagn Res.2015. 9(1): WC04-9.

7. Degitz, K., Ochsendorf, F. Acne. J. Dtsch. Dermatol. Ges. 2017. 15, 709-722.

8. Larkin, E.A., Carman, R.J., Krakauer, T., Stiles, B.G. Staphylococcus aureus: The toxic presence of a pathogen extraordinaire. Curr. Med. Chem. 2009. 16, 4003-4019. 
9. R. Hirano, T. H., Watanabe. Myanmar mango landraces reveal genetic uniqueness over common cultivars from Florida, India, and Southeast Asia. Genome. 2010. vol. 53, no. 4 , pp. 321-330.

10. Shah, K.A., Patel M.B., Patel R.J., Parmar, P.K. Mangifera indica (mango). Pharmacognosy Review. 2010. 4(7): 4248S.M.Y.2019

11. Berardini N., Fezer R., Conrad J., Beifuss U., Carl R., Schieber. Screening of mango (Mangifera indica L.) cultivars for their contents of flavonol O- and xanthone C-glycosides, anthocyanins, and pectin. Journal of Agricultural and Food Chemistry. 2005. vol. 53, no. 5, pp. 1563-1570.

12. Ling, L. T., Yap, S., Radhakrishnan, A. K., Subramaniam, T., Cheng, H. M., Palanisamy, U.D. Standardised Mangifera indica extract is an ideal antioxidant. Food Chemistry. 2009. $113,1154-1159$.

13. Bereksi, M. S., Hassaïne, H., Bekhechi, C., \& Abdelouahid, D. E. Evaluation of antibacterial activity of some medicinal plants extracts commonly used in Algerian traditional medicine against some pathogenic bacteria. Pharmacognosy Journal. 2018. 10(3).

14. Dellière, S., Verdurme, L., Bigot, J., Dannaoui, E., Senghor, Y., Botterel, F., Guitard, J. Comparison of the MICs Obtained by Gradient Concentration Strip and EUCAST Methods for Four Azole Drugs and Amphotericin B Against azolesusceptible and-resistant Aspergillus section Fumigati clinical isolates. Antimicrobial Agents and Chemotherapy. 2019. Vol 8.

15. Ditjen POM. Supplement 1 Pharmakopea Herbal Indonesia. Jakarta. 2008.

16. Dorta E, Gonzales M, Gloria Lobo M, Moreno Sanchez C, de Ancos.Screening of phenolic compounds in by-product extracts from mangoes (Mangifera indica L.) by HPLC-ESIQTOF-MS and multivariate analysis for use as a food ingredient.Food research international. 2014. 54:56
17. Jain, P., Bansal,D., Bhasin P., Anjali. Antimicrobial activity and phytochemical screening of five wild plants against Escherichia coli, Bacillus subtilis and Staphylococcus aureus. Journal of pharmacy research. 2010. 3(6):1260-1262

18. Kuete, V., Ngameni, B., Mbaveng, A. T., Ngadjui, B., Meyer, J. M., Lall, N. Evaluation of Flavonoids from Dorstenia Barteri for their Anti mycobacterial, Antigonorrheal and Anti-reverse Transcriptase Activities. Actatropica, 2010. 116(1), 100-104.

19. Madduluri, Suresh. Rao, K. Babu. Sitaram, B. In Vitro Evaluation of Antibacterial Activity of Five Indegenous Plants Extract Against Five Bacteria Pathogens of Human. International Journal of Pharmacy and Pharmaceutical Sciences. 2010. 5 (4): 679-684

20. Wang Q, Wang H, Xie M. Antibacterial mechanism of soybean isoflavone on Staphylococcus aureus. Arch Microbiol. 2010;192:893-8.

21. Chinnam N, Dadi P.K., Sabri S.A., Internasional M, Kabir M.A, Internasional Z. Dietary bioflavonoids inhibit Escherichia coli ATP synthase in a differential manner. Int $J$ Biol Macromol 2010;46:478-86.

22. Sahrawat A, Pal S, Shahi SK. Antibacterial activity of Mangifera indica (mango) leaves against drug resistant bacterial strains. Internasional Journal of Advanced Research. 2013; 1(6):82-86.

23. Savikin K, Menkovic N, Zdunic G, Stevic T, Radanovic D. Jankovic T. Antimicrobial activity of Gentiana lutea L. Extracts. Naturforsch. 2009; 64:339-342.

\section{Cite this article as:}

Novi Fajar Utami et al. Screening of mango leaves (Mangifera indica L.) varieties in Indonesia for antibacterial activity in Staphylococcus aureus. Int. J. Res. Ayurveda Pharm. 2020;11(2):77-80 http://dx.doi.org/10.7897/2277-4343.110234

Disclaimer: IJRAP is solely owned by Moksha Publishing House - A non-profit publishing house, dedicated to publishing quality research, while every effort has been taken to verify the accuracy of the content published in our Journal. IJRAP cannot accept any responsibility or liability for the site content and articles published. The views expressed in articles by our contributing authors are not necessarily those of IJRAP editor or editorial board members. 